\title{
Web 2.0 Supported Flipped Learning Model: EFL Students' Perceptions and
}

$$
\text { Motivation* }
$$

\author{
PInar GiRgiN ${ }^{a}$ (ORCID ID - 0000-0002-6611-8154) \\ Neşe CABAROĞLU ${ }^{b} *$ (ORCID ID - 0000-0002-2174-5410) \\ ${ }^{a}$ Çağ Üniversitesi, Mersin/Türkiye \\ ${ }^{b}$ *Çukurova Üniversitesi, Eğitim Fakültesi, Adana/Türkiye
}

\begin{tabular}{l}
\hline Article Info \\
\hline DOI: 10.14812/cufej.944217 \\
\hline Article history: \\
Received 31.05 .21 \\
Revised $\quad 10.08 .21$ \\
Accepted 20.08.21 \\
\hline Keywords: \\
Action research, English as a \\
foreign language, Flipped \\
classroom, Motivation, \\
Perceptions, Web 2.0 technology.
\end{tabular}

\begin{abstract}
This article presents an action research study examining the implementation of flipped classroom model supported with Web 2.0 technology to provide opportunities to use the target language and to motivate learners. Our participants were 12th grade language class students who were learning English as foreign language in a state school in Turkey. Our data came from a variety of sources including pre-and posttreatment questionnaires, teacher journals, lesson evaluation forms, observation tasks, and semi-structured interviews. Our findings revealed that participating students held positive perceptions and a high level of motivation towards the integration of Web 2.0 technology to Flipped Classroom in their English language learning process. Additionally, they reported a number of advantages associated with flipped learning model and Web 2.0 tools such as increased readiness to the lesson, improvement in variety of language and $4 C$ (i.e., critical thinking, creative thinking, communicating and collaborating) skills, fostered teamwork and boosted creativity. In light of our findings, we propose pedagogical implications for EFL practices.
\end{abstract}

\section{Web 2.0 Destekli Ters-Yüz Öğrenme Modeli: İngilizceyi Yabancı Dil Olarak Öğrenen Öğrencilerin Algıları ve Motivasyonları}

\begin{tabular}{|c|c|}
\hline \multicolumn{2}{|c|}{ Makale Bilgisi } \\
\hline \multicolumn{2}{|c|}{ DOI: 10.14812/cufej.944217 } \\
\hline \multicolumn{2}{|c|}{ Makale Geçmişi: } \\
\hline Geliş & 31.05 .21 \\
\hline Düzeltme & 10.08 .21 \\
\hline Kabul & 20.08 .21 \\
\hline \multicolumn{2}{|c|}{ Anahtar Kelimeler: } \\
\hline $\begin{array}{l}\text { Eylem ar } \\
\text { Yabancı Di } \\
\text { yüz öğrenr } \\
\text { Algılar, We }\end{array}$ & $\begin{array}{l}\text { aştırması, Ingilizcenin } \\
\text { I olarak Öğretimi, Ters- } \\
\text { ne modeli, Motivasyon, } \\
\text { b } 2.0 \text { teknolojisi }\end{array}$ \\
\hline
\end{tabular}

\section{Öz}

Bu çalışmada dil öğrenen öğrencilerin motivasyonlarını ve dil kullanımlarını arttırmak için web 2.0 teknolojisi ile desteklenen ters-yüz öğretme modelinin uygulanması incelenmiştir. Eylem araştırması modelinin kullanıldığı bu çalışmanın katılımcıları Türkiye'de bir devlet okulunda 12. sınıfa devam eden ve İngilizceyi yabancı dil olarak öğrenen öğrencilerdir. Çalışmada hem nitel hem de nicel veri toplama araçları kullanılmıştır. Bu araçlar: uygulama öncesi ve sonrası uygulanan anketler, öğretmen günlükleri, ders değerlendirme formları, gözlem görevleri ve yarı yapılandırılmış görüşmelerdir. Araştırma sonucunda elde ettiğimiz bulgular, katılımcı öğrencilerin İngilizce öğrenme süreçlerinde web 2.0 teknolojisinin ters-yüz sınıf modeline entegrasyonuna yönelik olumlu algılara ve yüksek düzeyde motivasyona sahip olduklarını ortaya koymuştur. Bu bulgulara ilaveten katılımcılar, ters yüz öğrenme modeli ve Web 2.0 araçlarına ilişkin olarak derse daha fazla hazır olma, çeşitli dil ve $4 C$ (iletişim kurma, iş birliği, yaratıcılık, eleştirel düşünme) becerilerinde gelişme, ekip çalışmasını teşvik etme ve yaratıcılıklarında artış gibi bir dizi avantaj bildirdiler. Araştırma bulguları ışı̆̆ında, İngilizceyi yabancı dil olarak öğrenme uygulamaları açısından pedagojik çıkarımlar yapılmıştır.

\section{Introduction}

In parallel with the rapid progress of technology, many educators are attempting to take progressive and creative steps to realign their teaching strategies. Often described as a reversed teaching model, the flipped classroom (FCM henceforth) is one of the innovative learning models that inverts the order of lecture in class- 
then-homework at home. Rather, course content is delivered to students at home through a large array of outof-class activities using various types of media (e.g., pre-recorded lectures, texts, pictures) while class time is used for (practical) application activities (e.g., problem solving, discussions and project designs), thus, maximizing student-learning opportunities and collaboration (Cummings, 2015). Related literature reveals vast differences in how teachers implement the classroom flip (Sierra, 2015) as well as in the selection and utilisation of variety of out-of-class and in-class activities (Delozier, 2017).

FCM is different from other teaching methods due to the continuous and pervasive utilization of interactive technological devices in the learning process (Strayer, 2012). One of the most significant facets of this model is the development of individual engagement for learning (Lee et al., 2018; Salimi \& Karimabadi, 2020). The FCM strengthens cooperation between students and teachers (Touchton, 2015), offers opportunities to create a learner-centred environment (Kiang \& Yunus, 2021) increases collaboration (Li \& Zhou, 2021) and motivation (Zhao, Liu \& Su, 2021).

The evidence for the use of FCM in language teaching and learning abounds and comes from multiple studies confirming positive effects of the FCM application on diverse range of language learning skills and competencies. Research on application of FCM in language teaching reveals improvement in writing skills and grammar (Öztürk \& Çakıroğlu, 2021) listening skills (Safiyeh \& Farrah, 2020), grammar and speaking skills (Köroğlu \& Çakır, 2017), pronunciation (Bin-Handy \& Hazaea, 2021), reading skills (Chotimah \& Rafi, 2018), collaborative skills (Hoy, 2016), vocabulary (Girgin, 2011), and 4C skills (i.e., communication, collaboration, creativity, critical thinking) (Kurniawati, 2020). It has also been reported that FCM increases learners' autonomy (Campillo-Ferrer \& Miralles-Martinez, 2021) and motivation (Santikarn \& Widhadee, 2018), promotes higher-level learning (Nederveld \& Berge, 2015) and active learning leading to greater gains in content knowledge (Webb \& Doman, 2016).

The design and management of the FCM is supported and enriched through web 2.0 technology. Also referred to as the second generation of the Internet, web 2.0 applications necessitate proactive role from their users and offer them the possibility of collaboration and interaction. Some examples of web 2.0 tools/applications are: social networking sites (Facebook or Twitter), image and video hosting sites (Flicker, You Tube), applications to generate web content for education (Padlet, Edmodo), and business (Wikipedia, Weebly). The value and importance of web 2.0 tools is now widely accepted and celebrated by language teachers as they offer numerous advantages. Integrating web 2.0 tools to the FCM enables students to be active participants and make contributions to the content, and also to create, monitor, and evaluate the context (Horzum, 2007).

Studies on language teaching and learning in Turkey show that language courses are usually teachercentred, too much emphasis is placed on grammar teaching and not much time is allocated for acquisition of language skills (Oktay, 2015). Furthermore, university entrance examinations have undesirable impacts on language teaching and learning (Yıldırım, 2010); students do not view foreign language as a means for communication; teaching/learning grammar, vocabulary, reading are (over) emphasized; speaking, listening and writing skills are neglected (Sevimli, 2007; Karabulut, 2007). These findings point to the washback effect, which regulates tendencies to fulfil testing needs (Cheng, 2003, 2005). As a result, learners are not capable of putting into practice what they learn. Teachers ought to create real-life atmospheres and practices that support learning and language skills. Incorporation of web 2.0 tools and FCM in language teaching may empower language learners as "learning is socially constructed through interaction with others and is expressed through a personal interpretation of knowledge" (Bustamante et al., 2012).

In light of the reviewed literature, the present study consequently attempts to explore language class students' perceptions and motivations of FCM and web 2.0 technology in the language learning process. When designing and implementing such tools in teaching, it is important that teachers make informed decisions to guide their choices and that they monitor what works and what does not. Despite the proliferation of research on flipped teaching and web 2.0 tools during the last decades, there still exists a need to investigate their effectiveness for learning English (Vitta \& Al-Hoorie, 2020) from the point of view of the learners. Reviewed 
literature also shows that although there are studies that focus on flipped learning and various web 2.0 tools in language teaching/learning, the number of studies examining their joint use and effect on learner motivation and perceptions of foreign language learning in Turkish EFL context is low, pointing to a need for comprehensive research on FCM through empirically supported activities. Moreover, the outbreak and subsequent pandemic of COVID 19 has forced teachers to re-think and re-design what and how they teach by using the multitudes of facilities online tools have to offer. As a consequence of pandemic, schools shut across the globe and education changed dramatically increasing reliance on education technology. Therefore, we believe that our study may inspire language teachers to open up opportunities and explore alternative approaches to teaching. With these considerations in mind, we designed our research to answer the following research questions:

- What are the students' motivations and perceptions towards the FCM and web 2.0 technology before implementing this model in learning English as a Foreign Language?

- How do FCM and web 2.0 tools affect students' motivations and perceptions after implementing them as Foreign Language teaching tools in learning English?

\section{Method}

\section{Research Design}

In order to alter and improve the teaching and learning process in a language class taught by one of the researchers, we designed our study as action research. Burns (1999) maintains that the purpose of action research is to bring about a shift and instruction progress. In practice, changes are derived from the analysis of data and information that provide the pace for change. Therefore, our study involved a four-stage process (i.e., planning, action, observation and reflection) and multiple cycles of data gathering (Kemmis \& Taggart, 2000) through a variety of data collection tools and procedures. The four-stage cyclical process enabled us to analyse the practices, take action to bring on improvements, and then become aware of what is going on and then go through the stages again (Hien, 2009).

\section{Research Setting and Participants}

The implementation of the study was completed in six weeks in the 2019-2020 academic year with 12thgrade EFL students in a language class in a public high school in Adana. At the beginning of the study, the students were informed about research purpose and procedures, and were asked if they would participate. Except for one, all the remaining students volunteered to participate in the study. Therefore, number of the students who took part in the study was nine (three males and six females/aged 17 years old). To gain access, permission was obtained from the parents of the students, who signed a consent form. Prior to commencing the study, Ethics Committee approvals (approval number: 23867972, 19/11/2019) and the School Principalship (approval number: 69527785-604.01.01-E.23446394, 27/11/2019) were also obtained.

All the participating students expressed a desire to pursue a career in teaching English in the future. The students had 14 hours (grammar=10 hours, vocabulary and reading= 4 hours) English lessons per week. Duration of each lesson was 40 minutes. They followed a coursebook published by the Ministry of Education as well as some other additional supplementary books and test-oriented materials that offered contents suitable for the university entrance language exam. Each classroom in the school was equipped with a smartboard and internet access.

\section{Action Research Procedures}

In the planning stage of the study, we assessed if the students had necessary devices and internet access to take part in the study. Eight participants had both smartphones and personal computers, while one participant had only a smartphone. Except for two participants who had access to internet at home only, all the remaining students had access to internet everywhere. This was followed by devising a six-week work plan (please see Appendix) to integrate the FCM and web 2.0 tools in and out of the classroom. Next, web 2.0 tools were identified in line with lesson goals and their usage. In order to enhance students' language skills and competencies, the following tools were used throughout the research cycle: Padlet (for exchanging pre- 
recorded lesson videos, texts, stories, and PowerPoint slides); Quizlet, Quizizz, Cram, and Kahoot (for generating quizzes, tests, flashcards, and educational games); Voki, GoAnimate, Animoto, and Powtoon (for constructing animations and videos based on the cloud); Canva and PosterMyWall (for poster and event creation); MindMeister (for brainstorming); StoryBird (to develop pictorial storybook). Before the application of these tools and after a pilot study, the pre-treatment questionnaire was administered to the participants.

During the action stage, the teacher-researcher displayed the web 2.0 tools on the smartboard and demonstrated how to use each tool step by step. Later, for each lesson, they were required to use the assigned tool. An account was created on Padlet to be used as a platform to exchange pre-recorded lesson videos and presentations, PowerPoints, and texts prepared by the teacher in line with the objectives of the curriculum for each lesson. Before coming to the class, students were required to watch the videos (for grammar lessons) and read the texts (for vocabulary and reading lessons). When in class, lesson content relevant to grammar topics were reviewed through PowerPoint presentations. In grammar lessons, in-class time was used to review the rules of grammar, create questions, animations, and educational games through Kahoot, Quizlet, Quizizz, Animoto, Powtoon, and PosterMywall. In reading and vocabulary lessons, MindMeister, Voki, Canva, Cram, GoAnimate, and Storybird web 2.0 tools were used to create mind maps with new words, posters, animations, and to develop their own stories. The students presented their products on the smartboard after each application and also exchanged the links to the activities on the Padlet.

Into the fifth week of the research, a teacher-colleague was invited to observe the teacher and students. During observations, the observer took notes and completed an observation task. Also, throughout the action stage, the teacher-researcher kept journals to jot down her reflections. This reflection phase involved assessing the challenges, benefits, and drawbacks of the implementation of each lesson. Journals, therefore, enabled us to analyse the experiences and processes of the work of students during the research activities. In addition to the teacher journals, lesson evaluation forms were completed by the students after each application. Finally, on the completion of our study, a post-treatment questionnaire was administered and semi-structured interviews were conducted.

\section{Research Instruments and Data Collection Procedures}

\section{Pre- and post-treatment questionnaires}

Pre- and post-treatment questionnaires were used in order to identify the changes (if any) in the participants' perceptions and motivation about the implementation of FCM and web 2.0 technology in language learning. The Motivation and Technology in English as a Foreign Language Classroom Questionnaire, adapted from ilter (2009), included a total of 20 questions. There were six open-ended questions and the remaining 14 questions were responded on a 3-item Likert-type scale ('Agree=1', 'Neutral=2' and 'Disagree=3').

\section{Peer observations}

In the second phase of the study, an external observer (i.e., a teacher colleague) conducted classroom observations lasting four hours in total (two hours in a grammar lesson and two hours in vocabulary and reading lesson) using an observation task. The task for grammar lessons was adapted from Tuna (2017), and vocabulary and reading observation task was developed by the researchers. The tasks included questions related to different stages of the lesson, observed impact(s) of classroom activities on the students, clarity of teacher instructions and delivery of the lessons, student participation and general views of the observer on the lesson.

\section{Lesson evaluation forms}

Immediately after the implementation of each web 2.0 tool, the students filled in the lesson evaluation forms. The form comprised of seven questions (six of which were open-ended) which sought students' thoughts and perceived impact of the web 2.0 tools on the language skills (Questions 1-4) and the level of motivation (Questions 2, 3, and 5), as well as the level of satisfaction with the teacher's application processes 
(Question 6). The last question (Question 7) included a scale ranging from 1 to 10 ("1= not motivated all" to "10= very motivated") to determine the students' self-reported motivation level for each tool.

\section{Teacher journal}

As explained earlier, immediately after the implementation of the FCM and each web 2. 0 tools, the teacher noted down own observations and reflections about a variety of issues such as problems encountered, students' motivation and participation, as well as perceived contribution of the tools to $4 \mathrm{C}$ skills. These reflections were also used as a guide to reshape consecutive lessons.

\section{Semi-structured interviews}

In line with the aim of the study, interviews were conducted in Turkish with all nine participants upon their consent. Each interview lasted approximately 13 to 15 minutes and was audio-recorded (upon their permission) and transcribed. Each interview was conducted at a pre-set time and location appropriate for the participants. It should be noted that careful consideration was given to the deliberate timing of interviews. To ensure the credibility of the findings, interviews were conducted right after final paper assignments were turned in, and were graded.

\section{Data Analysis}

In this study, the collected data were confined to conceptual content analysis (Wilkinson \& Birmingham, 2003) within a conceptual framework (Miles \& Huberman, 1994). Our conceptual framework was students' motivation and perceptions of FCM and web 2.0 technology in language learning. In line with this, revealing concepts were identified by clustering common or opposing opinions of the students (a step defined as initial coding), which was followed by the establishment of categories under which emerging concepts were subsumed. Finally, an external researcher holding a doctorate degree cross-checked the codes to ensure trustworthiness and credibility of the findings. To ensure trustworthiness and credibility of the findings variety of strategies were employed. These strategies are explained in relevant sections in the article.

A Statistical Package for Social Sciences (SPSS 22.0) was used to process data from the pre- and posttreatment questionnaires. Questionnaire items were grouped in accordance with independent variables to calculate descriptive statistics. The differences between the pre-and post-treatment questionnaires were compared using the Wilcoxon signed-rank test.

\section{Results}

\section{Pre-Treatment Questionnaire Findings}

The pre-treatment questionnaire consisting of 14 items, intended to explore students' perceptions and motivation towards FCM and web 2.0 usage in a language class. Table 1 portrays the findings from the questionnaire administered before the implementation.

Table 1.

Pre-Treatment Findings: The Effect of Technology on Students' Motivation and Perceptions

\begin{tabular}{|c|c|c|c|c|}
\hline & \multirow{2}{*}{$\mathrm{N}$} & Agree & Neutral & Disagree \\
\hline & & $f \%$ & $f \%$ & $f \%$ \\
\hline \multirow{2}{*}{$\begin{array}{l}\text { 1. Use of Technology in our language classrooms increases my } \\
\text { motivation. }\end{array}$} & \multirow{2}{*}{9} & 6 & 2 & 1 \\
\hline & & 66,7 & 22,2 & 11,1 \\
\hline \multirow{2}{*}{ 2. We should use technology in our classroom for every lesson. } & \multirow{2}{*}{9} & 2 & 6 & 1 \\
\hline & & 22,2 & 66,7 & 11,1 \\
\hline \multirow{2}{*}{$\begin{array}{l}\text { 3. Authentic materials downloaded from the internet make me } \\
\text { active in the learning process. }\end{array}$} & \multirow{2}{*}{9} & 9 & 0 & 0 \\
\hline & & 100 & 0 & 0 \\
\hline \multirow{2}{*}{$\begin{array}{l}\text { 4. Computer-based teaching activities make the lessons more } \\
\text { enjoyable. }\end{array}$} & \multirow{2}{*}{9} & 6 & 3 & 0 \\
\hline & & 66,7 & 33,3 & 0 \\
\hline
\end{tabular}


GiRGiN \& CABAROĞLU - Çukurova Üniversitesi Eğitim Fakültesi Dergisi, 50(2), 2021, 858-876

\begin{tabular}{|c|c|c|c|c|}
\hline 5. Technology can be boring and unnecessary. & 9 & $\begin{array}{c}1 \\
11,1\end{array}$ & $\begin{array}{c}4 \\
44,4\end{array}$ & $\begin{array}{c}4 \\
44,4\end{array}$ \\
\hline $\begin{array}{l}\text { 6. I can understand language better when my teacher uses } \\
\text { technology in the class. }\end{array}$ & 9 & $\begin{array}{c}4 \\
44,4\end{array}$ & $\begin{array}{c}4 \\
44,4\end{array}$ & $\begin{array}{c}1 \\
11,1\end{array}$ \\
\hline 7. We always need technological devices in language classrooms. & 9 & $\begin{array}{c}7 \\
77,8 \\
\end{array}$ & $\begin{array}{c}2 \\
22,2 \\
\end{array}$ & $\begin{array}{l}0 \\
0\end{array}$ \\
\hline $\begin{array}{l}\text { 8. Different technological devices should be used in the class to } \\
\text { increase my motivation for learning English. }\end{array}$ & 9 & $\begin{array}{c}7 \\
77,8 \\
\end{array}$ & $\begin{array}{c}1 \\
11,1 \\
\end{array}$ & $\begin{array}{c}1 \\
11,1\end{array}$ \\
\hline $\begin{array}{l}\text { 9. If my teacher uses PowerPoint presentations, lessons can be } \\
\text { more enjoyable. }\end{array}$ & 9 & $\begin{array}{c}3 \\
33,3\end{array}$ & $\begin{array}{c}2 \\
22,2\end{array}$ & $\begin{array}{c}4 \\
44,4\end{array}$ \\
\hline $\begin{array}{l}\text { 10. When we use technology every time, it makes the lessons } \\
\text { boring. }\end{array}$ & 9 & $\begin{array}{c}5 \\
55,6\end{array}$ & $\begin{array}{c}1 \\
11,1\end{array}$ & $\begin{array}{c}3 \\
33,3\end{array}$ \\
\hline $\begin{array}{l}\text { 11. Films, videos, CDs and e-learning can be helpful to develop my } \\
\text { language skills. }\end{array}$ & 9 & $\begin{array}{c}9 \\
100\end{array}$ & $\begin{array}{l}0 \\
0\end{array}$ & $\begin{array}{l}0 \\
0\end{array}$ \\
\hline $\begin{array}{l}\text { 12. I should use technology during my project works in EFL } \\
\text { classes. }\end{array}$ & 9 & $\begin{array}{c}5 \\
55,6 \\
\end{array}$ & $\begin{array}{c}4 \\
44,4 \\
\end{array}$ & $\begin{array}{l}0 \\
0\end{array}$ \\
\hline 13. My teacher should use more technology in the classrooms. & 9 & $\begin{array}{c}2 \\
22,2\end{array}$ & $\begin{array}{c}7 \\
77,8\end{array}$ & $\begin{array}{l}0 \\
0\end{array}$ \\
\hline $\begin{array}{l}\text { 14. Computer-based lessons are more enjoyable and effective } \\
\text { than traditional lessons. }\end{array}$ & 9 & $\begin{array}{c}2 \\
22,2\end{array}$ & $\begin{array}{c}6 \\
66,7\end{array}$ & $\begin{array}{c}1 \\
11,1\end{array}$ \\
\hline
\end{tabular}

As can be seen in the table, all nine participants agreed that the lessons with authentic materials are more enjoyable and that movies, videos, CDs in comparison with traditional classrooms and that e-learning can be beneficial in improving language skills. Only one student disagreed with item 1 ("Use of technology in our language classrooms increases my motivation") and item 14 ("Computer-based lessons are more enjoyable and effective than traditional lessons). Additionally, almost half of the students disagreed with items 5 ("Technology can be boring and unnecessary") and 9 ("If my teacher uses PowerPoint presentations, lessons can be more enjoyable.), which suggest a tendency in support of technology use in EFL classes. All in all, there seems to be a considerable improvement in student perceptions and motivation regarding the implementation of FCM and web 2.0 enhanced language classes.

\section{Post-Treatment Questionnaire Findings}

Post-treatment questionnaire was administered to the participants after the implementation of FCM and web 2.0 tools. Table 2 below reveals the findings from the questionnaire.

\section{Table 2.}

Post-Treatment Findings: The Effect of Technology on Student Motivation and Perceptions

\begin{tabular}{lcccc}
\hline & & Agree & Neutral & Disagree \\
\cline { 3 - 5 } & $N$ & $f(\%)$ & $f(\%)$ & $f(\%)$ \\
\hline $\begin{array}{l}\text { 1. Use of Technology in our language classrooms } \\
\text { increases my motivation. }\end{array}$ & 9 & 8 & 1 & 0 \\
\hline $\begin{array}{l}\text { 2. We should use technology in our classroom for } \\
\text { every lesson. }\end{array}$ & \multirow{2}{*}{8,89} & 6 & 11,1 & 0 \\
\hline $\begin{array}{l}\text { 3. Authentic materials downloaded from the } \\
\text { internet make me active in the learning process. }\end{array}$ & \multirow{2}{*}{66,7} & 9 & 0 & 0 \\
\hline $\begin{array}{l}\text { 4. Computer-based teaching activities make the } \\
\text { lessons more enjoyable. }\end{array}$ & \multirow{2}{*}{9} & 9 & 0 & 0 \\
\hline
\end{tabular}


GiRGiN \& CABAROĞLU - Çukurova Üniversitesi Eğitim Fakültesi Dergisi, 50(2), 2021, 858-876

\begin{tabular}{|c|c|c|c|c|}
\hline 5. Technology can be boring and unnecessary. & 9 & $\begin{array}{c}3 \\
3,33\end{array}$ & $\begin{array}{l}0 \\
0\end{array}$ & $\begin{array}{c}6 \\
66,7\end{array}$ \\
\hline $\begin{array}{l}\text { 6. I can understand language better when my } \\
\text { teacher uses technology in the class. }\end{array}$ & 9 & $\begin{array}{c}8 \\
88,9\end{array}$ & $\begin{array}{c}1 \\
11,1 \\
\end{array}$ & $\begin{array}{l}0 \\
0 \\
\end{array}$ \\
\hline $\begin{array}{l}\text { 7. We always need technological devices in } \\
\text { language classrooms. }\end{array}$ & 9 & $\begin{array}{c}6 \\
66,7\end{array}$ & $\begin{array}{c}2 \\
22,2\end{array}$ & $\begin{array}{c}1 \\
11,1\end{array}$ \\
\hline $\begin{array}{l}\text { 8. Different technological devices should be used in } \\
\text { the class to increase my motivation for learning } \\
\text { English. }\end{array}$ & 9 & $\begin{array}{c}7 \\
77,8\end{array}$ & $\begin{array}{c}1 \\
11,1\end{array}$ & $\begin{array}{c}1 \\
11,1\end{array}$ \\
\hline $\begin{array}{l}\text { 9. If my teacher uses PowerPoint presentations, } \\
\text { lessons can be more enjoyable. }\end{array}$ & 9 & $\begin{array}{c}9 \\
100 \\
\end{array}$ & $\begin{array}{l}0 \\
0 \\
\end{array}$ & $\begin{array}{l}0 \\
0\end{array}$ \\
\hline $\begin{array}{l}\text { 10. When we use technology every time, it makes } \\
\text { the lessons boring. }\end{array}$ & 9 & $\begin{array}{c}3 \\
33,3\end{array}$ & $\begin{array}{c}2 \\
22,2\end{array}$ & $\begin{array}{c}4 \\
44,4\end{array}$ \\
\hline $\begin{array}{l}\text { 11. Films, videos, CDs and e-learning can be helpful } \\
\text { to develop my language skills. }\end{array}$ & 9 & $\begin{array}{c}9 \\
100 \\
\end{array}$ & $\begin{array}{l}0 \\
0 \\
\end{array}$ & $\begin{array}{l}0 \\
0\end{array}$ \\
\hline $\begin{array}{l}\text { 12. I should use technology during my project } \\
\text { works in EFL classes. }\end{array}$ & 9 & $\begin{array}{c}6 \\
66,7 \\
\end{array}$ & $\begin{array}{c}3 \\
33,3 \\
\end{array}$ & $\begin{array}{l}0 \\
0\end{array}$ \\
\hline $\begin{array}{l}\text { 13. My teacher should use more technology in the } \\
\text { classrooms. }\end{array}$ & 9 & $\begin{array}{c}7 \\
77,8 \\
\end{array}$ & $\begin{array}{c}1 \\
11,1\end{array}$ & $\begin{array}{c}11,1 \\
0\end{array}$ \\
\hline $\begin{array}{l}\text { 14. Computer-based lessons are more enjoyable } \\
\text { and effective than traditional lessons. }\end{array}$ & 9 & $\begin{array}{c}6 \\
66,7 \\
\end{array}$ & $\begin{array}{c}3 \\
33,3 \\
\end{array}$ & $\begin{array}{l}0 \\
0 \\
\end{array}$ \\
\hline
\end{tabular}

As illustrated in the table, student perceptions and motivation about the use of technology in language classes were very positive for items 3 (use of authentic materials), 4 (computer-based teaching activities), 9 (PowerPoint presentations), and 11 (films, videos, CDs and e-learning). One student disagreed with items 1 (we always need technological devices in language classrooms), 8 (different technological devices should be used to increase motivation for learning English), and 13 (my teacher should use more technology in the classrooms), respectively. Almost half of the students disagreed with item 10, suggesting a positive change in the perception and motivation of students about the use of FCM and web 2.0 technology in language classrooms. All in all, there seems to be a considerable improvement in student perceptions and motivation regarding the use of technology in language classes.

\section{Comparison of Findings from Pre- and Post-Treatment Questionnaires}

The Wilcoxon paired-signed rank test was performed to determine whether there were any differences in the perceptions and motivation of students towards the integration of FCM and web 2.0 technology in English lessons. The test was analysed for each item separately. Table 3 shows the results.

Table 3.

Results of the Wilcoxon Paired-Signed Rank Test Comparing the Effect of Technology on Motivation in EFL Classrooms

\begin{tabular}{|c|c|c|c|c|c|c|}
\hline & Pair & $\mathrm{N}$ & Mean & SD & Z & $\mathrm{P}$ \\
\hline \multirow{2}{*}{$\begin{array}{l}\text { 1- The use of Technology in our language classrooms } \\
\text { increases my motivation. }\end{array}$} & Pre & \multirow{2}{*}{9} & 1,56 & 0,72 & \multirow{2}{*}{$-1,134$} & \multirow{2}{*}{0,257} \\
\hline & Post & & 1,89 & 0,33 & & \\
\hline \multirow{2}{*}{$\begin{array}{l}\text { 2- We should use technology in our classroom for } \\
\text { every lesson. }\end{array}$} & Pre & \multirow{2}{*}{9} & 1,11 & 0,60 & \multirow{2}{*}{$-2,236$} & \multirow{2}{*}{0,025} \\
\hline & Post & & 1,67 & 0,50 & & \\
\hline \multirow{2}{*}{$\begin{array}{l}\text { 3- Authentic materials downloaded from the internet } \\
\text { make me active in the learning process. }\end{array}$} & Pre & \multirow{2}{*}{9} & 2,00 & 0,00 & \multirow{2}{*}{0,000} & \multirow{2}{*}{1,000} \\
\hline & Post & & 2,00 & 0,00 & & \\
\hline \multirow{2}{*}{$\begin{array}{l}\text { 4- Computer-based teaching activities make the } \\
\text { lessons more enjoyable. }\end{array}$} & Pre & \multirow{2}{*}{9} & 1,67 & 0,50 & \multirow{2}{*}{$-1,732$} & \multirow{2}{*}{0,083} \\
\hline & Post & & 2,00 & 0,00 & & \\
\hline
\end{tabular}


GiRGiN \& CABAROĞLU - Çukurova Üniversitesi Eğitim Fakültesi Dergisi, 50(2), 2021, 858-876

\begin{tabular}{|c|c|c|c|c|c|c|}
\hline 5- Technology can be boring and unnecessary. & $\begin{array}{l}\text { Pre } \\
\text { Post }\end{array}$ & 9 & $\begin{array}{l}0,67 \\
0,67\end{array}$ & $\begin{array}{l}0,70 \\
1,00\end{array}$ & 0,000 & 1,000 \\
\hline \multirow{2}{*}{$\begin{array}{l}\text { 6- I can understand the language better when my } \\
\text { teacher uses technology in the class. }\end{array}$} & Pre & \multirow{2}{*}{9} & 1,33 & 0,70 & \multirow{2}{*}{$-1,890$} & \multirow{2}{*}{0,059} \\
\hline & Post & & 1,89 & 0,33 & & \\
\hline \multirow{2}{*}{$\begin{array}{l}\text { 7- We always need technological devices in language } \\
\text { classrooms. }\end{array}$} & Pre & \multirow{2}{*}{9} & 1,78 & 0,44 & \multirow{2}{*}{$-0,816$} & \multirow{2}{*}{0,414} \\
\hline & Post & & 1,56 & 0,72 & & \\
\hline \multirow{2}{*}{$\begin{array}{l}\text { 8- Different technological devices should be used in } \\
\text { the class to increase my motivation for learning } \\
\text { English }\end{array}$} & Pre & \multirow{2}{*}{9} & 1,67 & 0,70 & \multirow{2}{*}{$-1,342$} & \multirow{2}{*}{0,180} \\
\hline & Post & & 2,00 & 0,00 & & \\
\hline \multirow{2}{*}{$\begin{array}{l}\text { 9- If my teacher uses PowerPoint presentations, } \\
\text { lessons can be more enjoyable. }\end{array}$} & Pre & \multirow{2}{*}{9} & 0,89 & 0,92 & \multirow{2}{*}{$-2,271$} & \multirow{2}{*}{0,023} \\
\hline & Post & & 2,00 & 0,00 & & \\
\hline \multirow{2}{*}{$\begin{array}{l}\text { 10- When we use technology every time, it makes the } \\
\text { lessons boring. }\end{array}$} & Pre & \multirow{2}{*}{9} & 1,22 & 0,97 & \multirow{2}{*}{$-1,342$} & \multirow{2}{*}{0,180} \\
\hline & Post & & 0,89 & 0,92 & & \\
\hline \multirow{2}{*}{$\begin{array}{l}\text { 11- Films, videos, CDs and e-learning can be helpful to } \\
\text { develop my language skills. }\end{array}$} & Pre & \multirow{2}{*}{9} & 2,00 & 0,00 & \multirow{2}{*}{0,000} & \multirow{2}{*}{1,000} \\
\hline & Post & & 2,00 & 0,00 & & \\
\hline \multirow{2}{*}{$\begin{array}{l}\text { 12- I should use technology during my project works in } \\
\text { EFL classes. }\end{array}$} & Pre & \multirow{2}{*}{9} & 1,56 & 0,52 & \multirow{2}{*}{$-0,577$} & \multirow{2}{*}{0,564} \\
\hline & Post & & 1,67 & 0,50 & & \\
\hline \multirow{2}{*}{$\begin{array}{l}\text { 13- My teacher should use more technology in the } \\
\text { classrooms. }\end{array}$} & Pre & \multirow{2}{*}{9} & 1,22 & 0,44 & \multirow{2}{*}{$-1,633$} & \multirow{2}{*}{0,102} \\
\hline & Post & & 1,67 & 0,70 & & \\
\hline \multirow{2}{*}{$\begin{array}{l}\text { 14- Computer-based lessons are more enjoyable and } \\
\text { effective than traditional lessons. }\end{array}$} & Pre & \multirow{2}{*}{9} & 1,11 & 0,60 & \multirow{2}{*}{$-2,236$} & \multirow{2}{*}{0,025} \\
\hline & Post & & 1,67 & 0,50 & & \\
\hline
\end{tabular}

As presented in the table, the findings reveal significant differences $(p<0,05)$ for three items (i.e., items 2 , 9 , and 14) in particular. Our findings also point to a higher degree of motivation towards the implementation of technology in every lesson (Item 2). Although post-treatment questionnaire results for 6 items reveal a change in a positive direction, they are not statistically significant. Item 7, however, reveals a change between pre- and post-treatment in the negative direction; more than half of the students claimed that in language classes they always need technological devices. There was also a low score in Item 10, although the use of technology every time in class was in a positive direction. In addition, the results indicated that after the implementation of Items 3, 5 and 11, there was no improvement. Overall, our findings suggest positive changes in students' perceptions about the implementation of FCM and web 2.0 tools in English lessons.

\section{Students' Self-Reported Motivation towards Flipped Classroom and Web 2.0 Technology}

After implementation of FCM and web 2.0 technology in language teaching classes for six weeks, a motivation scale was administered to identify changes (if any) in students' motivation. After each implementation, students were asked to mark their motivation level for the 7th question in the lesson evaluation form (" $1=$ very low motivation" and " $10=$ highly motivated"). The table below reveals the mean values for each participant student. 
Table 4.

Student's Motivation after the Implementation of FCM and Web 2.0 Technology

\begin{tabular}{lllllllllllllll}
\hline S1 & 7 & 7 & 8 & 7 & 5 & 4 & 8 & 3 & 10 & 5 & 9 & 6 & $\mathbf{6 , 5 8}$ \\
S2 & 10 & 9 & 8 & 9 & 10 & 10 & 9 & 2 & 10 & 9 & 6 & 8 & $\mathbf{8 , 3 3}$ \\
S3 & 10 & 10 & 10 & 10 & 10 & 10 & 10 & 8 & 10 & 10 & 10 & 10 & $\mathbf{9 , 8 3}$ \\
S4 & 3 & 10 & 2 & 2 & 5 & 9 & 10 & 2 & 8 & 5 & 1 & 9 & $\mathbf{5 , 5 0}$ \\
S5 & 10 & 8 & 10 & 10 & 8 & 9 & 10 & 6 & 10 & 10 & 10 & 5 & $\mathbf{8 , 8 3}$ \\
S6 & 10 & 9 & 10 & 8 & 10 & 10 & 9 & 2 & 9 & 4 & 8 & 9 & $\mathbf{8 , 1 7}$ \\
S7 & 10 & 7 & 9 & 10 & 10 & 9 & 8 & 4 & 2 & 9 & 10 & 10 & $\mathbf{8 , 1 7}$ \\
S8 & 10 & 7 & 5 & 6 & 10 & 10 & 10 & 5 & 10 & 10 & 10 & 8 & $\mathbf{8 , 4 2}$ \\
S9 & 9 & 10 & 9 & 6 & 5 & 7 & 8 & 2 & 10 & 7 & 3 & 8 & $\mathbf{7 , 0 0}$ \\
\hline
\end{tabular}

As shown in the table, students' motivation levels were fairly high in general after each implementation. The results revealed that $S 4$ had the lowest motivation $(M=5,50)$ and that $S 3$ had the highest motivation level $(M=9,83)$. Our findings show that implementation of FCM and web 2.0 technology had a positive impact on student motivation at a higher degree in the English language learning process. The results reveal that FCM and web 2.0 implementations had a positive impact on students' motivation at a higher degree in the English language learning process.

\section{Findings from Lesson Evaluation Forms}

Based on our participants' responses to the open-ended questions in the lesson evaluation forms, all students indicated that they found FCM and web 2.0 incorporated lessons "useful" and "enjoyable". Through this mode of learning, they were able to "fill gaps in knowledge", were better prepared for the lesson due to the "rich content". Additionally, participants reported that implementation of tools made learning easy. To exemplify:

"Thanks to the web 2.0 tools we used, I learned synonyms of the words and easily comprehended grammar topics. This motivated me very much."

The students also stated that flipped learning promoted "active participation", and led to "permanent learning" as they were "authentic". In general, their perceptions regarding the effect of web 2.0 tools on variety of language skills were positive. Most of the students stated that the tools enhanced their reading, speaking, writing, vocabulary, grammar, and listening skills. One participant said:

"The application [i.e., Canva] helped me to improve both my writing and grammar. It was very enjoyable to create a story through my imagination and it sparked my creativity."

From among the 13 different web 2.0 tools used, Quizizz was not found to be useful in terms of enhancing language skills by one student. Similarly, all nine participants' evaluation of Quizlet tool in terms of its effect on their motivation was also in a negative direction. They all claimed that Quizlet "demotivated" them as it was "very complicated" and "boring."

Based on the comments in the lesson evaluation forms, participants' perceptions concerning the teacher's instructions and guidance were positive. More than half of the students stated that during the implementations, the teacher was "collaborative", "a good guide" and "a problem solver." Overall, students' perceptions on web 2.0 tools were in a positive direction and they were fairly satisfied.

\section{Findings from Peer Observation}

As explained earlier, an English teacher who worked at the same institution as the teacher-researcher observed the lessons using an observation task to record the observable effects of the FCM and web 2.0 tools on the students. The observer stated that the activities carried out in the classroom were beneficial in terms of 
developing "critical thinking", "creativity" and "collaboration" as well as improving "communication" and "problem-solving" skills. The observer added that throughout the activities the teacher was "cooperative", "supportive" and "communication-oriented" and played variety of roles including that of a "motivator", "facilitator", "problem solver" and "guide."

Regarding the students, the observer noted:

"All the students were able to practice their language skills [...] They used smartboards, tablets and web 2.0 tools related to the subject. The Quizizz application created a competitive classroom environment and encouraged participation and increased their engagement and motivation."

The observer further explained:

"Students were responsible for their own learning and were more exposed to the language [...] In a very supportive classroom environment, they performed a discussion relevant to the reading text and shared their ideas."

With regards to language skills, the observer stated:

"The students practiced their speaking, reading, and listening skills as well as grammar and vocabulary when going through the reading text. During the lesson, both the teacher and students spoke English when sharing thoughts which allowed learners to concentrate on listening and speaking skills as well as vocabulary. In the first stage of the lesson, reading skills were used when analysing the text. Students used the Canva application to generate their posters with the newly learned words, which was useful for practicing writing skills."

To conclude, the views of the observer revealed that the FCM atmosphere in which we incorporated web 2.0 tools in an EFL class affected the language learning of students in a positive direction.

\section{Findings from Teacher Journals}

In the first week of implementation, the students were enthusiastic. At times, internet connection was poor and this was resolved by changing the classroom. In the second week, one student said that although she initially assumed the lessons would be uninteresting, she really liked the PowerPoint presentations. On another occasion during an informal chat during a break, the students said that the pre-recorded lessons they watched on Padlet were very beneficial and understandable.

All the students came to the lesson prepared and participated in the activities eagerly while doing the hands-on activities through a variety of web 2.0 tools. One particular student, who had always been quiet and not so active in the previously held traditional lessons, participated often and was highly motivated during the activities. Also, when playing games through web 2.0 tools, they had fun and they said that learning new words was "easier" and that they "remembered well". During in-class activities, students were enthusiastic to answer the questions. After each lesson, they asked which web 2.0 tools would be used in the following week.

It should be noted that the students often had trouble using Quizlet which seemed to have lowered their motivation since they found it difficult to use. Apart from this, there was a collaborative classroom atmosphere: students were asking their peers for help to address challenges when they were creating animations, posters, and tests. Some students stated that the FCM gave them the chance to use the target language in "real-life" contexts and that solving tests in the conventional learning environment was "boring". When six weeks of implementation was over, all the students thanked for giving them the opportunity to incorporate technology into their language learning.

\section{Findings from Semi-Structured Interviews}

Upon the completion of the flipped teaching integrated with web 2.0 tools, we conducted interviews with nine participating students. Table 5 provides an overview of our findings. 
Table 5.

Students' Perceptions of FCM \& Web 2.0 Tools

\begin{tabular}{llc}
\hline & FCM & $\begin{array}{c}\text { Web } \\
2.0 \\
\text { Tools }\end{array}$ \\
\hline Increased readiness to the lesson & 7 & - \\
\hline Promoted active participation & 7 & 9 \\
\hline Led to better comprehension & 5 & - \\
\hline Reinforced learning & 2 & - \\
\hline Helped focus better & 1 & - \\
\hline Increased motivation & - & 9 \\
\hline Raised creativity & - & 9 \\
\hline Led to permanent learning & - & 1 \\
\hline Promoted/fostered teamwork & - & 5 \\
\hline Improved grammar & - & 9 \\
\hline Improved vocabulary & - & 9 \\
\hline Improved listening & - & 5 \\
\hline Improved speaking & - & 8 \\
\hline Improved reading & - & 9 \\
\hline Improved writing & - & 9 \\
\hline Promoted/developed critical thinking skills & - & 2 \\
\hline Boosted creativity & - & 9 \\
\hline Enjoyable/fun & 7 & - \\
\hline Authentic & - & 1 \\
\hline Rich in content & 1 & - \\
\hline Useful & 2 & - \\
\hline Educative & 1 & - \\
\hline Student-centred & 1 & - \\
\hline
\end{tabular}

Our first question was about the pre-recorded lesson component of flipped teaching. Majority of students found the pre-recorded videos useful in variety of ways as displayed in the table. To exemplify:

"I believe that those videos were essential tools for permanent learning [...] the videos helped me to understand the subject better and they reinforced what we studied."

Unlike others, two students' views about pre-recorded lessons were negative:

"In fact, as compared to my peers, my English is over average - so I got bored and skipped the videos. Instead, I got prepared for the topic using my grammar coursebook since I prefer traditional way of learning."

"I think it was just like traditional lessons. So, I did not benefit from them [...] if only conditions were different, I would benefit from them but now I prefer doing what's best for me, which is exam-oriented education."

Regarding perceived contributions, students unanimously mentioned that the tools improved their (language) skills as illustrated by the following extract:

“...for example, Kahoot, Quizlet, and Quizizz enhanced my grammar, and Cram and MindMeister enhanced my vocabulary. We have used Powtoon, GoAnimate, Animoto, and Voki for listening, writing, reading, and speaking...We designed our own animations and, when doing so, we learned and practiced new vocabulary, language forms, and vocalized characters. These activities have strengthened my language skills."

Participants further expressed that the tools enhanced their creativity and motivation: 
"I liked the tools that enabled us to create our animations because I like things that encourage me to create something. They were my favourites! We interacted with each other a lot. This increased our motivation."

The only negative comment given by the participants about the web 2.0 tools was concerned with the Quizlet. Students claimed that this tool was "complicated" and "difficult to use", hence "boring".

\section{Discussion \& Conclusion}

Our findings, triangulated through a variety of data sources, are noteworthy and point to pedagogical implications. Our study demonstrates how web 2.0 technology integrated FCM can be used in ways that are pedagogically effective. First, our data reveal that participants mostly held positive perceptions of FCM learning integrated with web 2.0 tools (Wulandari, 2017; Knezevic, Zupanec, \& Raduvolic, 2020). Second, in line with the literature our participants' self-reported motivation results point to an enhanced motivation for learning (Abdelrahman et al., 2017; Pozo-Sanchez, Lopez-Belmonte, Fuentes-Cabrera, Lopez-Nunez, 2021) and engagement of students (Bajurny, 2014; Alsowat, 2016). Third, our findings provide an insight into a variety of perceived pedagogical benefits of flipped language teaching integrated with web 2.0 tools. Resonating with other studies, these benefits consisted of: promoting higher levels of knowledge construction (Schellens \& Valcke, 2004) in, for example, grammar and vocabulary knowledge (Kang, 2015; Knezevic, Zupanec, \& Raduvolic, 2020) enhancing reading (Ökmen \& Kılıç, 2021), listening and speaking skills (Fethi \& Marshall, 2018; Liu, Zhang, Zhang, and Tian, 2020), writing skills (Ekmekçi, 2021; Ghufron \& Nudianingsih, 2021) as well as pronunciation (Bin-Hady \& Hazaea, 2021). Also, these tools increase interaction (Lee \& Martin, 2020) and collaboration (Ghufron \& Nudianingsih, 2021) through an active learning environment (Mu, 2017) by accommodating learner pace and space (Ramirez, 2018; Zainuddin \& Perera, 2018) and adding real-life relevance to the subject (Fulton 2012).

Another significant finding of the study confirms that FCM and technology-based lessons prepare students for in-class activities and lead to better understanding the topic of the lesson in that they provided more preparation time and allowed students to transfer theory into practice (Johnson, 2013) which resulted with improved interaction and participation in the class (Alghasab, 2020; Haghighi, Jafarigohar, Khoshsima, \&Vahdany, 2018). Additionally, similar to the findings of the previous studies almost all participants in the present study reported that the FCM fostered their 4C skills (i.e., critical thinking, creative thinking, communicating and collaborating) (e.g., Wu et al., 2017; Kurniawati, 2020).

Although our participants' perceptions were positive about the FCM and web 2.0 tools, some of them expressed reservations about their usefulness in terms of preparing them for the highly competitive university entrance exam. The exam has a considerable negative washback effect that prompts students to focus on explicit, formal aspects of language knowledge leaving out listening comprehension and speaking. For this reason, their preferences may not completely correspond to their responses. The negative impact of such high stakes exams on English language teaching/learning has been reported by previous studies (e.g., Saif, 2006; Deghaidy \& Nouby, 2008), a finding which might have some implications for curriculum developers and test makers.

To conclude, we claim that flipping a classroom may offer additional pedagogical benefits and that it requires investing effort, time and careful planning. This study shed light on an under-researched aspect of how or under what conditions a flipped approach integrated with web 2.0 technology in language teaching may be effective. Our small sample size could be considered both as a strength and a limitation; a strength as it enabled us to gain in-depth exploration of our research questions and a limitation in terms of generalizability. Therefore, future studies using larger sample sizes should further investigate the impact of flipped classrooms integrated with web 2.0 technology on various dimensions of language learning. Future studies are required, additionally, to find out long-term effectiveness of this mode of teaching on specific language skills/areas. Due to the lack of consensus in the literature, future studies may also delve into the impact of FCM on learners' academic performance (Sarli, 2019). 
All rules included in the "Directive for Scientific Research and Publication Ethics in Higher Education Institutions" have been adhered to, and none of the "Actions Contrary to Scientific Research and Publication Ethics" included in the second section of the Directive have been implemented.

\section{References}

Abdelrahman, L. A. M., DeWitt, D., Alias, N., \& Rahman, M. N. A. (2017). Flipped learning for ESL writing in a Sudanese school. TOJET, 16(3), 60-70.

Alghasab, M. B. (2020). Flipping the writing classroom: focusing on the pedagogical benefits and EFL learners' perceptions. English Language Teaching, 13(4), 28-40. https://doi.org/10.5539/elt.v13n4p28

Alsowat, H. (2016). An EFL flipped classroom teaching model: Effects on English language higher-order thinking skills, student engagement and satisfaction. Journal of Education and Practice, 7(9), 108-121.

Bajurny, A. (2014). An investigation into the effects of flip teaching on student learning. Unpublished master's thesis, University of Toronto, Canada.

https://tspace.library.utoronto.ca/bitstream/1807/67002/1/Bajurny Amy E 2014April MT MTRP.pdf

Bin-Hady, W.R.A., \& Hazaea, A.N. (2021), "EFL students' achievement and attitudes towards flipped pronunciation class: correlational study", PSU Research Review, (ahead-ofprint). https://doi.org/10.1108/PRR-09-2020-0029

Burns, A. (1999). Collaborative action research for English language teachers. Cambridge: Cambridge University Press.

Bustamante, C., Hurlbut, S., \& Moeller, A. K. (2012). Web 2.0 and language learners: moving from consumers to creators. Faculty Publications: Department of Teaching, Learning and Teacher Education. 180. http://digitalcommons.unl.edu/teachlearnfacpub/180

Campillo-Ferrer, J.M., \& Miralles-Martínez, P. (2021). Effectiveness of the flipped classroom model on students' self-reported motivation and learning during the COVID-19 pandemic. Humanities and Social Sciences Communications, 8, 1-9. https://doi.org/10.1057/s41599-021-00860-4

Cheng, L. (2003). Looking at the impact of a public examination change on secondary classroom teaching: A Hong Kong case study. Journal of Classroom Interaction, 38(1), 1-10.

Cheng, L. (2005). Changing language teaching through language testing: a washback study. Cambridge: Cambridge University Press.

Chotimah, I., \& Rafi, M. (2018). The effectiveness of using Kahoot as a media in teaching reading. E-Link Journal, 5(1), 19-29.

Cummings, L. (2015). Flipping the online classroom with web 2.0: the asynchronous workshop. Business \& Professional Communication Quarterly, 79(1), 81-101. https://doi.org/10.1177/2329490615602250

Deghaidy, H. E., \& Nouby, A. (2008). Effectiveness of a blend-ed e-learning cooperative approach in an Egyptian teacher education programme. Computers and Education, 51(3), 988-1006.

https://doi.org/10.1016/j.compedu.2007.10.001

Delozier, S. (2017). Flipped classrooms: a review of key ideas and recommendations for practice. Educational Psychology Review, 29(1), 141-151. https://doi.org/10.1007/s10648-015-9356-9 
Ekmekçi, E. (2021). The flipped writing classroom in Turkish EFL context: A comparative study on a new model. TOJET, 18(2), 151-167. https://doi.org/10.17718/tojde.306566

Fethi, K., \& Marshall, H. W. (2018). Flipping movies for dynamic engagement. In J. Mehring \& A. Leis (Eds.), Innovations in flipping the language classroom: Theories and Practices. (pp. 185-202). Singapore: Springer.

Fulton, K. (2012). Upside down and inside out: flip your classroom to improve student learning. Learning \& Leading with Technology, 39(8), 12-17.

Girgin, E. G. (2011). A web 2.0 tool for language teaching with flash content. Procedia Computer Science, 3, 627-631. https://doi.org/10.1016/j.procs.2010.12.105

Ghufron, M. A., \& Nurdianingsih, F. (2021). Flipped classroom method with computer-assisted language Learning (CALL) in EFL writing class. IJLTER, 20(1), 120-141. https://doi.org/10.26803/ij/ter.20.1.7

Hahighi, H., Jafarigohar, M., Khoshsima, H., \& Vahdany, F. (2019). Impact of flipped classroom on EFL learners' appropriate use of refusal: achievement, participation, perception. CALL, 32(3), 261-293.

https://doi.org/10.1080/09588221.2018.1504083

Hien, T. T. T. (2009). Why is action research suitable for education?. VNU Journal of Science, Foreign Languages, $25,97-106$

Horzum, M. B. (2007). Web based new instructional technologies: web 2.0 tools. Eğitim Bilimleri ve Uygulama [Educational Sciences and Practice], 6(12), 99-121.

Hoy, C. (2016). Using Edmodo to build personal learning networks and develop digital literacies. In A. Burns \& N. Kurtoğlu-Hooton (Eds.), Using Action Research to Explore Technology in Language Teaching: International Perspectives. (ELT research papers 16.06), (pp. 46-48). London: British Council.

Ilter, B. G. (2009). Effect of technology on motivation in EFL classrooms. TOJDE, 10(4), 136-158.

Johnson, G. B. (2013). Student perceptions of the flipped classroom. Unpublished master's thesis, The University of British Columbia, Canada. https://doi.org/10.14288/1.0073641

Kang, N. (2015). The comparison between regular and flipped classrooms for EFL Korean adult learners. Multimedia-Assisted Language Learning, 18(3), 41- 72. https://doi.org/10.15702/mall.2015.18.3.41

Karabulut, A. (2007). Micro level impacts of foreign language test (university entrance examination) in Turkey: a washback study. Unpublished master's thesis, lowa State University, Ames, USA. http://lib.dr.iastate.edu/rtd/14884/

Kemmis, S. and R. McTaggart. (2000). Participatory action research. In N. K. Denzin \& Y. S. Lincoln (Eds.), The Sage Handbook of Qualitative Research (pp. 559-603). Thousand Oaks, CA: Sage.

King, N. H. \& Yunus, M. M. (2021). What do Malaysian ESL teachers think about flipped classroom? International Journal of Learning, Teaching and Educational Research, 20(3), 117-131. https://doi.org/10.26803/ijlter.20.3.8

Köroğlu, Z. Ç., \& Çakır, A. (2017). Implementation of flipped instruction in language classrooms: an alternative way to develop speaking skills of pre-service English language teachers. IJEDICT, 13(2), 42-55. 
GiRGiN \& CABAROĞLU - Çukurova Üniversitesi Eğitim Fakültesi Dergisi, 50(2), 2021, 858-876

Knzevic, L., Zupanec, V., \& Raduvolic, B. (2020). Flipping the classroom to enhance academic learning in an English for Academic Purposes (EAP) Course. SAGE Open, 10(3), 1-15. https://doi.org/10.1177/2158244020957052

Kurniawati, N. (2020). Initiating flipped classroom informing the $4 \mathrm{C}$ skills among English education students. IJLECR, 6(1), 74-86. https:// doi.org/10.21009/IJLECR.061.11

Lee, Y. Y. \& Martin, K. I. (2020). The flipped classroom in ESL teacher education: An example from CALL. Education and Information Technologies, 25(4), 2605-2633. https://doi.org/10.1007/s10639-019-10082-6

Lee, L., Park, T., \& Davis, R. O. (2018). What affects learner engagement in flipped learning and what predicts its outcomes?: FL engagement and outcomes. British Journal of Educational Technology, 1(1), 118. https://doi.org/10.1111/bjet.12717

Leis, A. (2016). Flipped learning and EFL proficiency: an empirical study. TELES Journal, 36, 77-90.

Li, Z., \& Zhou, X. (2021). Flipping a virtual public speaking class integrated with Moocs during the Covid-19 pandemic. International Journal of TESOL Studies, 3(1), 178-195. https://doi.org/10.46451/ijts.2021.03.05

Liu, X., Zhang, L., Zhang, S., \& Tian, Y. (2020). The further study of the blended learning of the Video-aural-oral Course - the combination of web-based learning, flipped classroom and face-to-face instruction. Education Journal, 9(3), 64-72. https://doi.org/10.11648/j.edu.20200903.12

Miles, M. B., \& Huberman, A. M. (1994). Qualitative data analysis: an expanded sourcebook. Thousand Oaks, CA: Sage.

$\mathrm{Mu}$, Z. (2017). Affordance-based mobile learning in a flipped classroom to enhance CFL learners' oral proficiency: A comparative study. 2nd International Conference on Education, E-learning and Management Technology (EEMT), (pp. 106-11). Xi'an, China: DEStech Transactions on Social Science Education and Human Science. https://doi.org/10.12783/dtssehs/eemt2017/14417

Nederveld, A., \& Berge, Z. L. (2015). Flipped learning in the workplace. Journal of Workplace Learning, 27(2), 162-172.

Oktay, A. (2015). Foreign language teaching: a problem in Turkish education. Procedia - Social and Behavioral Sciences, 174, 584-593. https://doi.org/10.1016/j.sbspro.2015.01.587

Ökmen, B. \& Kılıç, A. (2021). The effect of layered flipped learning model on academic success. Participatory Educational Research, 8(3), 300-322. https://doi.org/10.17275/per.21.67.8.3

Öztürk, M., \& Çakıroğlu, Ü. (2021). Flipped learning design in EFL classrooms: implementing self-regulated learning strategies to develop language skills. Smart Learning Environments, 8(2), 1-20. https://doi.org/10.1186/s40561-021-00146-x

Pozo-Sanchez, S., Lopez-Belmonte, Fuentes-Cabrera, A., \& Lopez-Nunez, J. (2021). Twitch as a technopedagogical resource to complement the flipped learning methodology in a time of academic uncertainty. Sustainability, 13(9), 1-13. https://doi.org/10.3390/su13094901

Ramirez, M. (2018). In-class flip: flipping a literature class for student-centered learning. In J. Mehring \& A. Leis (Eds.), Innovations in flipping the language classroom: Theories and Practices (pp. 185-202). Singapore: Springer.

Safiyeh, H. A., \& Farrah, M. (2020). Investigating the effectiveness of flipped learning on enhancing students' English language skills. English Review: Journal of English Education, 9(1), 193-204. https://doi.org/10.25134/erjee.v9i1.3799 
Saif, S. (2006). Aiming for positive washback: a case study of international teaching assistants. Language Testing, 23(1), 1-34. https://doi.org/10.1191/0265532206lt322oa

Salimi, E. A. \& Karimabadi, M. (2020). The efficacy of classroom flipping on Iranian intermediate EFL learners' engagement and their perception of the Flipped Classroom Model. JTLS, 3(2), 143-180. https://doi.org.10.22099/jtls.2021.38824.2901

Santikarn, B., \& Wichadee, S. (2018). Flipping the classroom for English language learners: A study on learning performance and perceptions. iJET, 13(9), 123-135. https://doi.org/10.3991/ijet.v13i09.7792

Sarli, M. A. (2019). Perceptions of International Students in Poland regarding flipped classrooms. (Unpublished doctoral dissertation). Walden University, USA.

https://scholarworks.waldenu.edu/cgi/viewcontent.cgi?article=8354\&context=dissertations

Schellens, T., \& Valcke, M. (2004). Fostering knowledge construction in university students through asynchronous discussion groups. Computers \& Education, 46(4), 349-370. https://doi.org/10.1016/j.compedu.2004.07.010

Sevimli, S. E. (2007). The washback effects of foreign language component of the university entrance examination on the teaching and learning context of English language groups in secondary education: a case study. Unpublished master's thesis, Gaziantep University, Turkey. https://tez.yok.gov.tr/UlusalTezMerkezi/.

Sierra, H. (2015). Students' experiences in a math analysis flipped classroom. Unpublished master's thesis, Chapman University, California, USA.

https://kenanaonline.com/files/0102/102659/Students\%E2\%80\%99\%20Experiences\%20in\%20a\%20Math\%20A nalysis\%20Flipped\%20Classroom.pdf

Strayer, J.F. (2012). How learning in an inverted classroom influences cooperation, innovation and task orientation. Learning Environment Research, 15(2), 171-193. https://doi.org/10.1007/s10984-012-9108-4

Touchton, M. (2015). Flipping the classroom and student performance in advanced statistics: evidence from a quasi-experiment. Journal of Political Science Education, 11(1), 28-44. https://doi.org/10.1080/15512169.2014.985105

Tuna, G. (2017). An action study on college students' EFL writing skills development through flipped classroom environments. Unpublished master's thesis, Middle East Technical University, Turkey. https://open.metu.edu.tr/bitstream/handle/11511/27053/index.pdf

Vitta, J. P., \& Al-Hoorie, A. H. (2020). The flipped classroom in second language learning: a meta-analysis. Language Teaching Research, 1(1), 1-25. https://doi.org/10.1177/1362168820981403

Webb, M., \& Doman, E. (2016). Does the flipped classroom lead to increased gains on learning outcomes in ESL/EFL contexts? CATESOL Journal, 28(1), 39-67.

Wilkinson, D., \& Birmingham, P. (2003). Using research instruments: a guide for researchers. London: Routledge Falmer.

Wu, W. C. V., Hsieh, J. S. C., \& Yang, J. C. (2017). Creating an online learning community in a flipped classroom to enhance EFL learners' oral proficiency. Journal of Educational Technology \& Society, 20(2), 142-157. 
Wulandari, M. (2017). Fostering learning autonomy through the implementation of flipped learning in language teaching media course. IJIET, 1(2), 194-205. https://doi.org/10.24071/ijiet.2017.010209

Yıldırım, Ö. (2010). Washback Effects of a High-Stakes University Entrance Exam: Effects of the English Section of the University Entrance Exam on Future English Language Teachers in Turkey. Asian EFL Journal, 2(12), 92-116.

Zainuddin, Z., \& Perera, C. J. (2018). "Supporting students' self-directed learning in the flipped classroom through the LMS TES BlendSpace", On the Horizon, 26(4), 281-290. https://doi.org/10.1108/ OTH-04-20170016

Zhao, L., Liu, L., \& Su, Y-S. (2021). The differentiate effect of self-efficacy, motivation, and satisfaction on preservice teacher students' learning achievement in a flipped classroom: A case of a modern educational technology course. Sustainability, 13(5), 1-15. https://doi.org/10.3390/su13052888 


\section{Appendix}

Weekly Plan for Implementing Flipped Classroom Model Integrated with Web 2.0 Tools

\begin{tabular}{|c|c|c|c|c|}
\hline $\begin{array}{c}\text { Week } \\
\text { \& Duration }\end{array}$ & Lesson & Objectives & Activities & Web 2.0 Tools \\
\hline $\begin{array}{l}\text { 1st Week } \\
\text { (10 hours) }\end{array}$ & Grammar & $\begin{array}{c}\text { - to use the } \\
\text { pronouns }\end{array}$ & $\begin{array}{l}\text { - watching pre-recorded } \\
\text { lesson videos on Padlet (out- } \\
\text { of-class task) } \\
\text { - preparing quiz-game on } \\
\text { Kahoot } \\
\text { - playing quiz-game on Kahoot } \\
\text { (in-class activities) }\end{array}$ & $\begin{array}{l}\text { Padlet } \\
\text { Kahoot } \\
\text { PowerPoint } \\
\text { slides }\end{array}$ \\
\hline $\begin{array}{l}\text { 1st Week } \\
\text { (4 hours) }\end{array}$ & $\begin{array}{l}\text { Reading \& } \\
\text { Vocabulary }\end{array}$ & $\begin{array}{l}\text { - to learn new } \\
\text { words \& use } \\
\text { them in real-life } \\
\text { contexts } \\
\text { - to enhance } 4 C^{\prime} \text { 's } \\
\text { skills } \\
\end{array}$ & $\begin{array}{l}\text { - reading an article on Padlet } \\
\text { (out-of-class task) } \\
\text { - group-discussion } \\
\text { - preparing their own mind } \\
\text { maps (in-class activity) }\end{array}$ & $\begin{array}{l}\text { Padlet } \\
\text { Mindmeister }\end{array}$ \\
\hline $\begin{array}{l}\text { 2nd Week } \\
\text { (10 hours) }\end{array}$ & Grammar & $\begin{array}{l}\text { - to use the } \\
\text { simple present, } \\
\text { present } \\
\text { continuous, } \\
\text { simple past } \\
\text { tenses }\end{array}$ & $\begin{array}{l}\text { - watching pre-recorded } \\
\text { lesson videos on Padlet (out- } \\
\text { of-class task) } \\
\text { - preparing their own test, } \\
\text { word- game on Quizlet } \\
\text { - solving test and playing word } \\
\text { games on Quizlet (in-class } \\
\text { activities) }\end{array}$ & $\begin{array}{l}\text { Padlet } \\
\text { Quizlet } \\
\text { PowerPoint } \\
\text { slides }\end{array}$ \\
\hline $\begin{array}{l}\text { 2nd Week } \\
\text { (4 hours) }\end{array}$ & $\begin{array}{l}\text { Reading \& } \\
\text { Vocabulary }\end{array}$ & $\begin{array}{l}\text { - to learn new } \\
\text { words \& use } \\
\text { them in real-life } \\
\text { contexts } \\
\text { - to enhance } \\
\text { speaking \& } \\
\text { reading skills } \\
\text { - to enhance 4C's } \\
\text { skills }\end{array}$ & $\begin{array}{l}\text { - reading an article on Padlet } \\
\text { (out of class task) } \\
\text { - group-discussion; preparing } \\
\text { videos with avatars (in-class } \\
\text { activity) }\end{array}$ & $\begin{array}{l}\text { Padlet } \\
\text { Voki }\end{array}$ \\
\hline $\begin{array}{l}\text { 3rd Week } \\
\text { (10 hours) }\end{array}$ & Grammar & $\begin{array}{l}\text { - to use the } \\
\text { present perfect, } \\
\text { present perfect } \\
\text { continuous, past } \\
\text { perfect and past } \\
\text { perfect } \\
\text { continuous } \\
\text { tenses }\end{array}$ & $\begin{array}{l}\text { - watching pre-recorded } \\
\text { lesson videos on Padlet (out- } \\
\text { of-class task) } \\
\text { - creating posters (in-class } \\
\text { activity) }\end{array}$ & $\begin{array}{l}\text { Padlet } \\
\text { PosterMyWall } \\
\text { PowerPoint } \\
\text { slides }\end{array}$ \\
\hline $\begin{array}{l}\text { 3rd Week } \\
\text { (4 hours) }\end{array}$ & $\begin{array}{l}\text { Reading \& } \\
\text { Vocabulary }\end{array}$ & $\begin{array}{l}\text { - to learn new } \\
\text { words } \\
\text { - to enhance } \\
\text { speaking \& } \\
\text { reading skills } \\
\end{array}$ & $\begin{array}{l}\text { - reading an article on Padlet } \\
\text { (out-of-class task) } \\
\text { - group-discussion; creating } \\
\text { flashcards, and playing } \\
\text { games (in-class activity) }\end{array}$ & $\begin{array}{l}\text { Padlet } \\
\text { Cram }\end{array}$ \\
\hline
\end{tabular}




\begin{tabular}{|c|c|c|c|c|}
\hline & & $\begin{array}{l}\text { - to enhance } 4 C^{\prime} \text { s } \\
\text { skills }\end{array}$ & & \\
\hline $\begin{array}{l}\text { 4th Week } \\
\text { (10 hours) }\end{array}$ & Grammar & $\begin{array}{l}\text { - to use the future } \\
\text { perfect, future } \\
\text { continuous, \& } \\
\text { future perfect } \\
\text { continuous }\end{array}$ & $\begin{array}{l}\text { - watching pre-recorded } \\
\text { lesson videos on Padlet (out- } \\
\text { of-class task) } \\
\text { creating animations and } \\
\text { videos (in-class activities) }\end{array}$ & $\begin{array}{l}\text { Padlet } \\
\text { GoAnimate } \\
\text { PowerPoint } \\
\text { slides }\end{array}$ \\
\hline $\begin{array}{l}\text { 4th Week } \\
\text { (4 hours) }\end{array}$ & $\begin{array}{l}\text { Reading \& } \\
\text { Vocabulary }\end{array}$ & $\begin{array}{l}\text { - to learn new } \\
\text { words } \\
\text { - to enhance } \\
\text { speaking \& } \\
\text { reading skills } \\
\text { - to enhance 4C's } \\
\text { skills }\end{array}$ & $\begin{array}{l}\text { - reading a text on Padlet } \\
\text { (out-of-class task) } \\
\text { - group-discussion; creating } \\
\text { own stories on StoryBird (in- } \\
\text { class activities) }\end{array}$ & $\begin{array}{l}\text { Padlet } \\
\text { StoryBird }\end{array}$ \\
\hline $\begin{array}{l}\text { 5th Week } \\
\text { (10 hours) }\end{array}$ & Grammar & $\begin{array}{l}\text { - to use the } \\
\text { active-passive } \\
\text { voice }\end{array}$ & $\begin{array}{l}\text { - watching pre-recorded } \\
\text { lesson videos on Padlet (out- } \\
\text { of-class task) } \\
\text { - preparing tests on Quizizz } \\
\text { (in-class activity) }\end{array}$ & $\begin{array}{l}\text { Padlet } \\
\text { Quizizz }\end{array}$ \\
\hline $\begin{array}{l}\text { 5th Week } \\
\text { (4 hours) }\end{array}$ & $\begin{array}{l}\text { Reading \& } \\
\text { Vocabulary }\end{array}$ & $\begin{array}{l}\text { - to learn new } \\
\text { words } \\
\text { - to enhance } \\
\text { speaking \& } \\
\text { reading skills } \\
\text { - to enhance 4C's } \\
\text { skills } \\
\end{array}$ & $\begin{array}{l}\text { - reading a short story on } \\
\text { Padlet (out-of-class task) } \\
\text { - group-discussion; creating } \\
\text { posters on Canva (in-class } \\
\text { activity) }\end{array}$ & $\begin{array}{l}\text { Canva } \\
\text { Padlet }\end{array}$ \\
\hline $\begin{array}{l}\text { 6th Week } \\
\text { (10 hours) }\end{array}$ & Grammar & $\begin{array}{l}\text { - to use the } \\
\text { relative clause }\end{array}$ & $\begin{array}{l}\text { - watching pre-recorded } \\
\text { lesson videos on Padlet (out- } \\
\text { of-class task) } \\
\text { - creating animations and } \\
\text { videos on PowToon (in-class } \\
\text { activities) }\end{array}$ & $\begin{array}{l}\text { Padlet } \\
\text { PowToon } \\
\text { PowerPoint } \\
\text { slides }\end{array}$ \\
\hline $\begin{array}{l}\text { 6th Week } \\
\text { (4 hours) }\end{array}$ & $\begin{array}{l}\text { Reading } \\
\text { \&Vocabulary }\end{array}$ & $\begin{array}{l}\text { - to learn new } \\
\text { words } \\
\text { - to enhance } \\
\text { speaking \& } \\
\text { reading skills } \\
\text { - to enhance 4C's } \\
\text { skills }\end{array}$ & $\begin{array}{l}\text { - reading a short story on } \\
\text { Padlet (out-of-class task) } \\
\text { - group-discussion; creating } \\
\text { videos on Animoto (in-class } \\
\text { activities) }\end{array}$ & $\begin{array}{l}\text { Padlet } \\
\text { Animoto }\end{array}$ \\
\hline
\end{tabular}

